\title{
The Relationship of Working Period with the Incidence of Occupational Contact Dermatitis in Haji Adam Malik General Hospital Medan
}

\author{
Veronica ${ }^{1}$, N. Z. Lubis ${ }^{2}$ \\ ${ }^{1}$ Faculty of Medicine, Universitas Sumatera Utara, Medan, North Sumatera, Indonesia \\ ${ }^{2}$ Department of Dermatology and Venereology, Faculty of Medicine, Universitas Sumatera Utara, \\ Medan, North Sumatera, Indonesia
}

\begin{abstract}
Occupational skin diseases are the third most common occupational diseases. The most common occupational skin diseases are contact dermatitis covering 90-95\%. The majority of contact dermatitis occurs in the hands. This study aims to determine the relationship of working period with the incidence of occupational contact dermatitis in cleaning service workers at Haji Adam Malik General Hospital Medan. This study is analytic method study which uses cross sectional design and uses questionnaire. Respondent were drawn using consecutive sampling. The study showed that 33,2\% of cleaning service workers had contact dermatitis. The prevalence of contact dermatitis in women $75,8 \%$ and men $24,2 \%$. The contact time for workers who come into contact chemical $>2$ hours is $100 \%$. The use of PPE on cleaning service workers is $89,3 \%$. Most ethnic group suffering from contact dermatitis are the 77,4\% Batak people. The highest level cleaning service education is high school 59,4\%. The results of the analysis with the chi square test of working life with the incidence of occupational contact dermatitis were $(p=0,383)$. There is no significant relationship of working period with the incidence of occupational contact dermatitis in cleaning service workers at Haji Adam Malik General Hospital Medan.
\end{abstract}

Received 18 December 2019 | Revised 14 June 2020 | Accepted 18 July 2020

\section{Introduction}

Occupational diseases are exposures that occur in the workplace that cause a condition or worsen an existing condition [1]. Occupational skin diseases are the third most frequent occupational diseases [2]. Decreased productivity and work capacity, lost work due to illness, and medical expenses are losses due to occupational skin diseases estimated at more than 1 billion dollars per year only in the United States alone $[3,4,5]$. The most common occupational dermatitis are contact dermatitis cover $90-95 \%$ and include irritant contact dermatitis and allergic contact dermatitis $[4,6]$.

Contact dermatitis tends to occur in types of work that have a source of primary irritants and allergens [7]. The national prevalence of dermatitis is $6,8 \%$ (based on respondents' complaints).

\footnotetext{
*Corresponding author at: Faculty of Medicine, Universitas Sumatera Utara, Medan, North Sumatera, Indonesia 
A total of 14 provinces have a prevalence of dermatitis above the national prevalence, namely Nanggroe Aceh Darussalam, West Sumatera, Bengkulu, Bangka Belitung, DKI Jakarta, West Java, Central Java, DI Yogyakarta, East Nusa Tenggara, Central Kalimantan, South Kalimantan, North Sulawesi, Central Sulawesi, and Gorontalo [8]. The Centers for Disease Control and Prevention in 2013 stated that occupational contact dermatitis is divided into two categories, irritant contact dermatitis and allergic contact dermatitis. Irritant Contact Dermatitis (ICD) is a non-immunological reaction in the form of inflammation of the skin caused by direct damage to the skin due to exposure to hazardous substances. ICD reaction specifically in the contact area. Allergic Contact Dermatitis (ACD) is inflammation of the skin due to an immune reaction caused by contact with an allergen on condition that allergen must be sensitized beforehand. Reactions not only limited to the site of contact but also a systemic response can occur [9].

Occupational contact dermatitis is predominantly affecting the hands. Most workers will continue to work, more than half will change their jobs, and a large proportion will be absent from work for several months or more [10]. Research conducted on Semarang Mrican tofu workers about the relationship of work period ( $\leq 2$ years and $>2$ years) with the incidence of irritant contact dermatitis showed a relationship with $\mathrm{p}$ value $=0,001$ [11]. In the study of premix workers at PT.X Cirebon work period with the incidence of irritant contact dermatitis has no relationship with $\mathrm{p}$ value $=1[12]$.

Decree of the Minister of Health of the Republic of Indonesia No.1204/ Menkes/ SK/ X/ 2004 explains that the hospital is a health service facility where the sick or healthy people gather or can be a place of disease transmission and allows environmental pollution and health problems [13]. In hospitls, both state-owned enterprise hospital or private hospitals, the burden of cleaning service work is heavier. This is because the patients come and go. Surely the patient has garbage in the room, either food waste or others [14]. Based on the background above I would like to research at Haji Adam Malik General Hospital Medan to see if there is a relationship working period with the incidence of contact dermatitis in cleaning service workers.

\section{Method}

This research method is observational analytic with cross sectional approach. In cross sectional studies the independent variables/ risk factors and the dependent variables were assessed simultaneously at one time [15]. This research was conducted at Haji Adam Malik General Hospital Medan in July 2019 to December 2019 with the target population being cleaning service workers, while the accessible population in this study were all cleaning service workers in Haji Adam Malik General Hospital, Medan. Sampling method is consecutive sampling in accordance with the criteria of inclusion and exclusion, where the samples are taken in the order of coming to meet the minimum number of samples. 
Determination of sample size in research use the formula :

$n=\frac{\mathrm{Z}^{2}{ }_{1-\alpha / 2} \mathrm{p}(1-\mathrm{p}) \mathrm{N}}{d^{2}(N-1)+Z^{2} 1-\frac{\alpha}{2} \mathrm{p}(1-\mathrm{p})}$

Information :

$\mathrm{n} \quad=$ minimum number of samples that is required

$Z_{1-\alpha 2}=$ research power with $\alpha=5 \%(1,96)$

$\mathrm{p} \quad=$ proportion of cases studied in the population, if not known use the largest $\mathrm{p}$ $(0,5)$

$\mathrm{N}=$ total population (362 workers cleaning service)

$\mathrm{d} \quad=$ fault tolerance $(0,05)$

The minimum number of samples from this study is 187 people. Sampling using consecutive sampling techniques. The research tool used was the 2002 NOSQ questionnaire with data collection using cross sectional techniques and conducting interviews.

Data processing and analysis use 5 stages, namely data collection, data processing, data presentation, data analysis/ interpretation, and conclusions. The data obtained is entered into SPSS (Statistical Package for the Social Sciences) and distributed using frequency distribution tables, cross tabulation tables, and carried out discussions using existing libraries. Next do a bivariate analysis to see whether there is relationship between independent variable and the dependent variable. The statistical test used is the chi-square test which is a non-parametric hypothesis test. If the significance limit $(\alpha<0,05)$ with the meaning having a significant relationship between the independent variable and the dependent variable. If $p>\alpha$ is obtained, there is no significant relationship beteween the independent variable and the dependent variable.

\section{Result}

\subsection{Characteristics Data of Respondents}

The characteristics contained in the study include gender, age, ethnicity of respondents, last education, working period, frequency of exposure, duration of exposure, usa of Personal Protective Equipment (PPE) can be seen in the table below :

Table 1 Characteristics of Respondents

\begin{tabular}{llcc}
\hline No & Data & $\begin{array}{c}\text { Accuracy } \\
(\%)\end{array}$ \\
\hline & & Sex & \\
\hline 1 & Male & & 26,7 \\
2 & Female & & 73,3 \\
\hline & & Age & \\
\hline 3 & $<25$ years & & 43,3
\end{tabular}




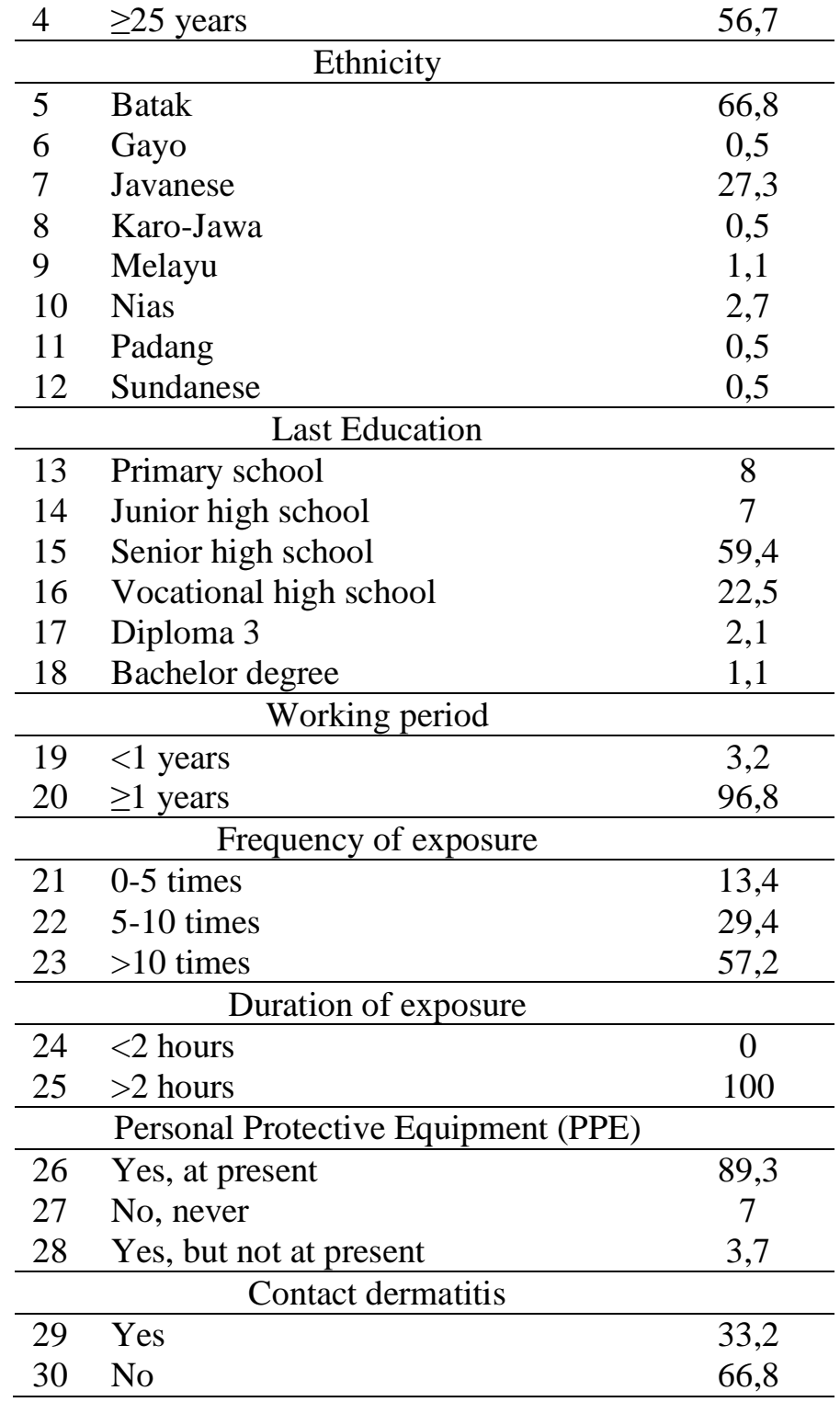

\subsection{Prevalence of Occupational Contact Dermatitis in Men and Women}

Below are the prevalence of occupational contact dermatitis in men and women cleaning service workers :

Table 2 Prevalence contact dermatitis in men and women

\begin{tabular}{ccc}
\hline \multirow{2}{*}{ Sex } & \multicolumn{2}{c}{ Incidence of Contact Dermatitis } \\
\cline { 2 - 3 } & Yes (\%) & No (\%) \\
\hline Man & 24,2 & 28 \\
Woman & 75,8 & 72 \\
\hline
\end{tabular}

\subsection{Most Ethnicity Who Suffer From Occupational Contact Dermatitis}

The following are the ethnicity that suffer from contact dermatitis in cleaning service workers : 
Table 3 The people who suffer from occupational contact dermatitis

\begin{tabular}{lcc}
\hline \multirow{2}{*}{ Ethnicity } & \multicolumn{2}{c}{ Incidence of Contact Dermatitis } \\
\cline { 2 - 3 } & Yes $(\%)$ & No $(\%)$ \\
\hline Batak & 77,4 & 61,6 \\
Gayo & 0 & 0,8 \\
Javanese & 14,5 & 33,6 \\
Karo-Jawa & 0 & 0,8 \\
Melayu & 1,6 & 0,8 \\
Nias & 4,8 & 1,6 \\
Padang & 1,6 & 0 \\
Sundanese & 0 & 0,8 \\
\hline
\end{tabular}

\subsection{History of Atopic Symptoms}

The following is a history of atopic symptoms in cleaning service workers :

Table 4 Itchy rash that has been coming and going for at least 6 months, allergic rhinitis, allergy on eyes, asthma

\begin{tabular}{lcc}
\hline \multirow{2}{*}{ History of Atopic Symptoms } & \multicolumn{2}{c}{ Incidence of Contact Dermatitis } \\
\cline { 2 - 3 } & \multicolumn{1}{c}{ Yes (\%) } & No (\%) \\
\hline Itchy rash that has been coming and going & \\
\hline Yes & 32,3 & 9,6 \\
No & 67,7 & 90,4 \\
\hline Allergy on eyes & 43,5 & 32 \\
\hline Yes & 33 & 67,2 \\
No & 3,2 & 0,8 \\
Don't know & & \\
\hline Asthma & 6,5 & 4,8 \\
\hline Yes & 93,5 & 93,6 \\
No & 0 & 1,6 \\
Don't know & & \\
\hline Diagnosed with asthma & 1,6 & 0,8 \\
\hline Yes & 4,8 & 4 \\
No & & \\
\hline
\end{tabular}

\subsection{Dermatitis}

The following are areas of eczema on the hands, wrists, or forearms, doctor's visit to cleaning service workers, dry and itchy skin due to sweating with incidence of occupational contact dermatitis :

Table 5 Areas of eczema on the hands, wrists, or forearms

\begin{tabular}{llc}
\hline No & \multicolumn{1}{c}{ Data } & Accuracy $(\%)$ \\
\hline 1 & Fingers & 12,3 \\
2 & Finger webs & 18,2 \\
3 & Backs of hands & 10,7 \\
4 & Palms & 15,5 \\
5 & Wrists & 12,3 \\
6 & Forearms & 13,4 \\
& & \\
\hline
\end{tabular}


Table 6 Doctor's visit on cleaning service workers

\begin{tabular}{llc}
\hline No & Data & Accuracy (\%) \\
\hline 1 & Yes & 3,2 \\
2 & No & 96,8 \\
\hline
\end{tabular}

Table 7 Dry and itchy skin due to sweating with incidence of occupational contact dermatitis

\begin{tabular}{lccc}
\hline \multirow{2}{*}{ Data } & \multicolumn{2}{c}{ Incidence of Contact Dermatitis } & \multirow{2}{*}{ P value } \\
\cline { 2 - 3 } & Yes (\%) & No (\%) & \\
\cline { 1 - 2 } Dry skin & & & \\
\hline Yes & 35,5 & 22,4 & 0,057 \\
No & 64,5 & 77,6 & \\
\hline \multicolumn{1}{l}{ Itchy skin due to sweating } & & \\
\hline Yes & 50 & 30,4 & 0,009 \\
No & 50 & 69,6 & \\
\hline
\end{tabular}

\subsection{Exposures}

The following are types of gloves that are using, symptoms, and rashes on the skin after wearing gloves :

Table 8 Types of gloves to wear

\begin{tabular}{llc}
\hline No & \multicolumn{1}{c}{ Data } & Accuracy $(\%)$ \\
\hline 1 & Natural rubber/ latex & 71,7 \\
2 & Latex examination glove & 9,1 \\
3 & Synthetic rubber & 5,3 \\
4 & Cloth & 16 \\
\hline
\end{tabular}

Table 9 Symptoms and rashes on the skin after wearing gloves

\begin{tabular}{llc}
\hline No & Data & Accuracy (\%) \\
\hline \multicolumn{2}{l}{ Symptoms } & \\
$1 \quad$ Yes & 28,3 \\
$2 \quad$ No & 64,7 \\
Rashes on the skin & \\
$3 \quad$ Itchy & 24,1 \\
$4 \quad$ Redness & 10,7 \\
$5 \quad$ Dry & 3,7 \\
$6 \quad$ Tiny water blisters & 0,5 \\
& (vesicles) \\
7 & Papules \\
8 & Calluses & 0,5 \\
9 & Burning, pricking, or & 0,5 \\
& stinging & 0,5 \\
\hline
\end{tabular}

\subsection{Relationship of Working Period with the Incidence of Contact Dermatitis}

Table 10 Relationship of Working Period with the Incidence of Contact Dermatitis

\begin{tabular}{cccc}
\hline \multirow{2}{*}{$\begin{array}{c}\text { Working } \\
\text { Period }\end{array}$} & \multicolumn{2}{c}{$\begin{array}{c}\text { Incidence of Contact } \\
\text { Dermatitis }\end{array}$} & P value \\
\cline { 2 - 3 } & Yes $(\%)$ & No $(\%)$ & \\
\hline$<1$ years & 1,6 & 4 & 0,383 \\
$\geq 1$ years & 98,4 & 96 & \\
\hline
\end{tabular}




\section{Discussion}

\subsection{Characteristics Data of Respondents}

The number of respondents collected was 187 people. Table 1 shows that the most respondents are women $(73,3 \%)$. At the most age is $\geq 25$ years old $(56,7 \%)$. The most ethnic group is the Batak people $(66,8 \%)$. The most recent education was high school $(59,4 \%)$. The most working period is $\geq 1$ years $(96,8 \%)$. The most frequent exposure to hand washing was $>10$ times $(57,2 \%)$. The duration of exposure was $\geq 2$ hours (100\%). At present $89,3 \%$ respondents use PPE (Personal Protective Equipment). The number of respondents who experienced contact dermatitis was $33,2 \%$.

\subsection{Prevalence of Occupational Contact Dermatitis in Men and Women}

Table 2 shows that more women $(75,8 \%)$ had contact dermatitis than men $(24,2 \%)$. Data from the National Health Interview Survey shows more women than men (58\% vs $42 \%)$ and a greater prevalence of health workers $[6,16]$. Irritant contact dermatitis is significantly more frequent in women than men. Occupational contact dermatitis is more than twice that of women than men. This is due to environmental factors and not genetic factors. Women have a greater role to clean the house and look after children at home also most do a lot of work that has a great risk for irritant contact dermatitis [17].

\subsection{Most Ethnicity Who Suffer From Occupational Contact Dermatitis}

Table 3 shows that the highest incidence of occupational contact dermatitis is Batak people $(77,4 \%)$ is due to the greater number of Batak workers. There is little significant evidence of irritant response among the Caucasian, black, and Asian groups and there is no consensus on whether ethnicity is an endogenous factor for irritant contact dermatitis [18]. There is no relationship between ethnicity and the incidence of allergic contact dermatitis [19].

\subsection{History of Atopic Symptoms}

Table 4 shows that 32,3\% had experienced an itchy rash that coming and going for 6 months and at one time had affected skin folds (folds of the elbows, back of the knees, front of elbows, under the buttocks, around the neck, ears, and eyes), 58,1\% had allergic rhinitis, 43,5\% had allergies in the eyes, and $6,5 \%$ had asthma with $1,6 \%$ diagnosed by a doctor suffering from asthma and $4,8 \%$ not diagnosed by a doctor. In studies with car mechanics, a history of atopic was found in more than $31,3 \%$ of workers wirh occupational contact dermatitis [20].

\subsection{Dermatitis}

Table 5 shows that the most eczema areas in cleaning service workers were finger webs $18,2 \%$. Finger webs is the first place affected, but inflammation can extend to the fingers, back of the hand, and wrist [21]. Cumulative irritant contact dermatitis more often affects thin skin, such as the back of the hand and between the fingers [22].

Table 6 shows that $96,8 \%$ respondents did not visit the doctor for eczema. This contradicts research conducted in Denmark where more people visit doctors for eczema on the hands $(84,5 \%)[23]$. This is probably because eczema on the hands does not interfere with daily activities. 
Table 7 shows that dry skin has no relationship with the incidence of occupational contact dermatitis with a $p$ value of 0,057 . The $p$ value is significant if $p<0,05$. This contradicts researchs in cloth-manufacturing workers in Beijing with dry skin having a relationship with the incidence of occupational contact dermatitis $(p<0,001)$ [24]. In itchy skin when sweating with the incidence of contact dermatitis there is a significant relationship ( $\mathrm{p}$ value $=0,009$ ). Hot workplaces cause sweating which can dissolve several types of industrial chemical powders thereby increasing toxicity to the skin [25].

\subsection{Exposures}

Table 8 shows that the most gloves used in cleaning service workers are natural rubber/ latex $(71,7 \%)$. Natural rubber and latex examination glove are used to clean the room while synthetic rubber and cloth gloves are used by cleaning service workers in the park with cloth gloves used to sweep the yard while synthetic rubber is used to clean trenches.

Table 9 shows that cleaning service workers had symptoms and rashes on the skin after wearing gloves $(28,3 \%)$ and most common symptoms were skin itching $(24,1 \%)$. Irritant dermatitis usually occurs on the hands of people who wear latex or rubber gloves, but neither the latex glove nor has any additional chemicals that irritate the skin. Gloves also trap moisture in the skin, making the skin softer and more susceptible to irritation. The most frequent symptoms are redness and itching of the skin [26].

\subsection{Relationship of Working Period with the Incidence of Contact Dermatitis}

Table 10 shows that after bivariate analysis with chi-square on a significance level of $0,05 \%$ $(\alpha=5 \%)$, the $p$ value is 0,383 ( $p>0,005)$ which means that there is no significant relationship of working period with the incidence of occupational contact dermatitis to cleaning service workers. This is consistent with research on shipyard workers in Samarinda with $p=1$ [12] and research on laundry employees in Semarang with $p=0,384$ [27]. No significant relationship possibly because of good knowledge using PPE (Personal Protective Equipment) at work. The majority of respondents working for $>1$ year $(96,8 \%)$ and workers who work $>1$ year have experience to minimize contact and be careful about substances that can cause contact dermatitis [12]. Workers with working period $\leq 2$ years is one factor that workers do not have enough experience in doing their jobs. This has the potential to increase the incidence of contact dermatitis in workers with working period $\leq 2$ years $[28,11]$.

\section{Conclusion}

There is no relationship of working period with the incidence of occupational contact dermatitis in cleaning service workers and there is a relationship of itchy skin when sweating with the incidence of occupational contact dermatitis. 


\section{REFERENCES}

[1] Bepko J, Mansalis K. Common Occupational Disorders: Asthma, COPD, Dermatitis, and Musculoskeletal Disorders. American family physician. 2016 Jun 15;93(12).

[2] Ivanov, D.I. The Global Occupational Health Network. Available at : https://www.who.int/ceh/gohnet_18_3.pdf. Sept 2011

[3] Mancini, A.J., Kaulback, K. , Chamlin, S.L. The socioeconomic impact of atopic dermatitis in the United States: a systematic review. Pediatriac Dermatol. 2008; 25: 1-6.

[4] Cashman, M.W. , Reutemann, P.A. , Ehrilich, A. Contact dermatitis in the United States: epidemiology, economic impact, and workplace prevention. Dermatol Clin. 2012; 30: 8798.

[5] Anderson SE, Meade BJ. Potential health effects associated with dermal exposure to occupational chemicals. Environmental health insights. 2014 Jan;8:EHI-S15258.

[6] Pacheco KA. Occupational dermatitis: How to identify the exposures, make the diagnosis, and treat the disease. Annals of Allergy, Asthma \& Immunology. 2018 Jun 1;120(6):58391.

[7] James, W., Elston, D.M., Treat, J.R., Rosenbach, M.A., Neuhaus, I.M. Andrews' Diseases of The Skin, Twelfth Edition. United States : Elsevier; 2016

[8] Riset Kesehatan Dasar. Laporan Nasional 2007, Badan Penelitian dan Pengembangan Kesehatan, Republik Indonesia. Des 2008.

[9] Centers for Disease Control and Prevention. Skin Exposure \& Effects. The National Institute for Occupational Safety and Health. Jul 2013.

[10] Wikinson, S.M. Dermatology, Fourth Edition. United States : Elsevier. pp 274- 285. 2018.

[11] Pradaningrum S, Lestantyo D, Jayanti S. HUBUNGAN PERSONAL HYGIENE, LAMA KONTAK, DAN MASA KERJA DENGAN GEJALA DERMATITIS KONTAK IRITAN PADA PENGRAJIN TAHU MRICAN SEMARANG. Jurnal Kesehatan Masyarakat (e-Journal). 2018 Jul 1;6(4):378-86.

[12] Indrawan IA, Suwondo A, Lestantyo D. Faktor-faktor yang berhubungan dengan kejadian dermatitis kontak iritan pada pekerja bagian premix di PT. X Cirebon. Jurnal Kesehatan Masyarakat (e-Journal). 2014;2(2):110-8.

[13] Keputusan Menteri Kesehatan RI No 1204/Menkes/SK/X/2004. Available at : http://www.pdpersi.co.id/peraturan/kepmenkes/kmk12042004.pdf

[14] Mukriani. Analisis Kesejahteraan Cleaning Service di Rumah Sakit Umum Daerah (RSUD) Cut Nyak Dhien Meulaboh Kecamatan Johan Pahlawan Kabupaten Aceh Barat, Available at : http://repository.utu.ac.id/583/1/I-V.pdf . 2016.

[15] Ghazali M.V., Sastroamihardjo S., Soedjarwo, S.R., Soelaryo, T., Pramulyo, H.S. 'Dasardasar Metodologi Penelitian Klinis',Jakarta : CV. Sagung Seto. 2014.

[16] Luckhaupt, S.E., Dahlhamer, J.M., Ward, B.W. et al. Prevalence of dermatitis in the working population, United States, 2010 National Health Interview Survey. Am J Ind Med. 2013; 56: 625-634

[17] Aneja, S. Irritant Contact Dermatitis. Available at : https://emedicine.medscape.com/article/1049353-overview\#a5. 2019.

[18] Modjtahedi SP, Maibach HI. Ethnicity as a possible endogenous factor in irritant contact dermatitis: comparing the irritant response among Caucasians, blacks, and Asians. Contact dermatitis. 2002 Nov;47(5):272-8.

[19] Helm, T.N., 'What are the race, sex, and age-related demographics of allergic contact dermatitis?' accessed 26 November 2019, Available at : https://www.medscape.com/answers/1049216-4816/what-are-the-race-sex-and-agerelated-demographics-of-allergic-contact-dermatitis. 2019

[20] Attwa E, El-Laithy N. Contact dermatitis in car repair workers. Journal of the European Academy of Dermatology and Venereology. 2009 Feb;23(2):138-45.

[21] Oakley, A.and Koch, K. 'Hand dermatitis', Available at : https://dermnetnz.org/topics/hand-dermatitis/. 2018.

[22] Agarwal US, Besarwal RK, Gupta R, Agarwal P, Napalia S. Hand eczema. Indian journal of dermatology. 2014 May;59(3):213.

[23] Lysdal, S. H. 'PhD thesis Occupational hand eczema and its career consequences among trained hairdressers : a register based questionnaire study'. 2011. 
[24] Chen YX, Cheng HY, Li LF. Prevalence and risk factors of contact dermatitis among clothing manufacturing employees in Beijing: a cross-sectional study. Medicine. 2017 Mar;96(12).

[25] Canadian Centre for Occupational Health and Safety. Dermatitis, Allergic, Contact. Available at : https://www.ccohs.ca/oshanswers/diseases/allergic_derm.html. Sept 2016.

[26] Weston, W.L, Howe, W., Patient education : Contact dermatitis (including latex dermatitis)(Beyond the Basics). Available at : https://www.uptodate.com/contents/contact-dermatitis-including-latex-dermatitis-beyondthe-basics. 2019

[27] Afifah A, Ernawati D, Sudaryanto S. Faktor-faktor yang berhubungan dengan terjadinya dermatitis kontak akibat kerja pada karyawan binatu (Doctoral dissertation, Fakultas Kedokteran). 2012.

[28] Cohen DE. Occupational Dermatosis. Handbook of Occupational Safety and Health 2nd ed. 1999

[29] Susitaival P, Flyvholm MA, Meding B, Kanerva L, Lindberg M, Svensson A, Olafsson JH. Nordic Occupational Skin Questionnaire (NOSQ-2002): a new tool for surveying occupational skin diseases and exposure. Contact dermatitis. 2003 Aug;49(2):70-6. 